\title{
The Moderating Effect of Audit Opinion on The Local Government Financial Performances and The Disclosure Compliance of Financial Information
}

\author{
Jamal Akrom ${ }^{1 *}$ and Amrie Firmansyah ${ }^{2}$ \\ ${ }^{1,2}$ Polytechnic of State Finance (STAN), Indonesia
}

\begin{abstract}
This study is aimed to analyze the effect of financial performance indicators such as absorption of local expenditure ratio, effectiveness ratio, and financial independence ratio on the disclosure compliance of financial information on the website, as well as audit opinion as moderating variable. The sample of the study is the local governments in Java with consisting of 81 selected local governments within three years period. The data are analyzed with multiple regression analysis using the fixed-effect method.

The results show that the absorption of the local budget ratio cannot encourage the disclosure compliance of financial information on the website. While the effectiveness ratio and the financial independence ratio are positively associated with the disclosure compliance of financial information on the website. This study also finds that audit opinion weakens the effect of financial independence ratio on the disclosure compliance of financial information on the website. However, audit opinion cannot moderate the effect of absorption of local budget ratio and the effectiveness ratio on the disclosure compliance of financial information on the website.
\end{abstract}

Keywords: audit opinion; financial performances, information.

\section{INTRODUCTION}

The reform of the state financial sector has been started since the acts regulating state finance were enacted. Those acts are expected to increase accountability and transparency in terms of the state financial management. The government financial statement is one form of the government performances accountability to stakeholders. The government financial statement contains numbers which show the results of the government financial management in a certain period in accordance with the Government Regulation No. 71 of 2010 concerning Governmental Accounting Standards.

The Indonesian citizens demand that public sector organizations must improve its quality, professionalism, and accountability in conducting the government programs. It encourages that audit not only conducted to fulfill compliances but also to asses the performances (Badjuri and Trihapsari, 2004). To measure how well the government's financial performance can be conducted by calculating contained numbers in the financial statements using financial

* Corresponding author. Email address: jamalakrom@gmail.com 
performance indicators. Furthermore, the Supreme Audit Agency has a role to ensure state financial management accounted properly.

The provisions in The Act No. 14 of 2008 concerning Public Information Openness, regulates the duty of every public institution to announce all public information periodically. The Publication of local government financial managements is specifically regulated in Article 302 of Minister of Home Affairs Decree No. 13 of 2006 concerning Local Government Financial Management Guidelines which states that the audited financial statements must be published. The Indonesian citizens as one of the government stakeholders have the right to obtain information related to financial management accountability undertaken by the local government. Financial reporting using the internet can be used as an alternative method of reporting to demonstrate the commitment of local government to be accountable and transparent. A website is a tool that supports the delivery of information to the public in an efficient way and it influences aspects of financial reporting. Using the Internet as one of the media to disclose financial information have several advantages such as accounting data electronically can be accessed anytime and anywhere (Xiao, et al., 2005). In addition, the Internet also allows two-way communication (, 2010). Previously, the development of the website to improve public transparency has been regulated by Indonesian Presidential Instruction No. 3 of 2003 on National Policy and Strategy Development of E-Government. Furthermore, The Minister of Home Affairs Instruction No. 188-52 / 1797 / SJ of 2012 on Improving Transparency of Local Budget Management regulates more specific about public transparency. By these provisions, the head of local governments is obliged to prepare content menus "Transparency of Local Budget Management" on the authorized websites. The contents which are required to The Minister of Home Affairs Instruction such as the latest data related the summary of Budget Work Plan, Local Government Budget Draft included the amendment, the summary of the Budget Implementation Document, the Budget Realization Statements; the Audited Local Government Financial Statements. Actually, the Instruction was authorized in 2012, but there is no the consequences or the sanctions if local governments do not implement the instructions.

The studies related to financial disclosure compliances on websites or Internet Financial Reporting (IFR) have been conducted with various measurements and different results. The study on the disclosure compliance of financial information on the website in New Zealand has been conducted by Laswad, et al. (2005). The result shows that local government performance is associated with internet financial reporting. This result is in line with a study conducted by Suhardjanto and Lesmana (2010) and Setyaningrum and Syafitri (2012). While Puspita and Martani (2012) prove the different results that the performance of the local government has no effect on the disclosure of financial information on the website. Puspita and Martani (2012) explain that the difference results with Laswad, et al. (2005) may be expected because of the use of wider disclosure index. A similar study conducted Hiola, et al. (2016) by taking the object in the Sulawesi region for the period of study during 2013. The study conducted Hiola, et al. (2016) use three indicators of financial performances, namely the Absorption of Local Expenditure and the Effectiveness Ratio, as also used in research Puspita and Martani (2012), the independence ratio, used Suhardjanto and Lesmana (2010); Setyaningrum and Safitri (2012), as one of the variables of the 
study, as well as the audit opinion and political environment as a moderating variable.

The results of that study show that the better financial performance of a Local Government, the more obedient Local Government in disclosing financial information on its official website. All three indicators of financial performances namely the absorption of local expenditures ratio, the effectiveness ratio, and the financial independence ratio as used Hiola, et al (2016) are associated with the disclosure of financial information on the Local Government official website. Meanwhile, Puspita and Martani (2012) show the different result that the absorption of local expenditures ratio, the effectiveness ratio is not associated with the disclosure of financial information on the website. Furthermore, the local financial independence ratio is in line with the results of Suhardjanto and Lesmana (2010) which shows the local financial independence has significant influence. However, this finding is not relevant to the results of Setyaningrum and Syafitri (2012) which indicates that the local financial independence ratio is not associated with the disclosure of financial performances on the local government website.

Hiola et al. (2016) also find that the audit opinion can moderate the effect of the financial performances on the compliance disclosure of financial information on the website. Directly, the better the audit opinion obtained by a Local Government, the higher financial information disclosure conducted by a local Government. However, the audit opinion can weaken financial disclosures on its website on some local governments that received opinion other than a qualified opinion. While the political environment variables can not moderate the effect of the financial performance on the compliance disclosure of financial information on the website. In addition, Hiola, et al. (2016) find the level of disclosure compliance with financial information on the website (IFR) Local Governments in the region of Sulawesi is still low, supported by the fact that there are local governments which do not provide the content as required in the instructions of the Minister of Home Affair number 188-52 / 1797 / SJ of 2012 on Improving Transparency of Local Budget Management.

The results of previous studies seemed still not consistently so that it is needed to investigate further the topic with different objects using the local governments in Java Island. Using samples the local governments in Java Island, it is considered that there are still different characters between the local governments in Java and Sulawesi in terms of size and level of welfares, so that it is expected to gain different results. Moreover, the previous research has limitations, using one year period so that the opportunity for us to conduct research using more than one year period to determine whether there are differences in compliance with financial disclosures. In addition, the research on compliance with disclosure of financial information on the website is still rarely conducted especially associated with government requirements as regulated in The Minister of Home Affair Instruction number 188-52 / 1797 / SJ of 2012 on Improving Transparency of Local Budget Management. Furthermore, based on the summary of the second mid-term 2015 examination results of the Supreme Audit Board, audit opinion of financial statements of local governments in Java are better than those of other regions. 


\section{LITERATURE REVIEW AND HYPOTHESIS}

\subsection{Theoretical Framework}

\subsubsection{Stakeholders Theory}

According to Freeman (1984), stakeholders in terms of the business are the groups or individuals who are affected and affect the company's future. Whereas in the context of the organization, both of the government and the private sectors, Bryson (1995) defines stakeholders as an individual, groups or organizations that can make claims or resources or attention to the organization's output or affected by that. The discussion in terms of the government stakeholders including local government accountability is inseparable from the government performances as stated in the financial statements. While, Drebin et al., (1981) explains that the government stakeholders can be grouped into taxpayers, donors, investors, service users, employees, suppliers, the legislative, the government itself, the voters and audit institutions. The provisions of Government Regulation No. 71 of 2010 On the Government Accounting Standards, mention some of the main groups of users of the government financial statements as a society; representatives, regulatory agencies, and audit institutions; donors, investments and loans; and the Government. Each user groups may require different information. Anthony (1978) divides the four needs of users of the government financial statements namely financial viability, fiscal compliance, performance management, and cost of service provided.

Since there are various of stakeholders who need the information from the financial statements, the Government should provide the well-structured financial information and in accordance with the standards or the regulations. Thus, all the information presented in the financial statements of local government can be used as a basis for planning, controlling and decision-making, especially for the local government as well as societies as taxpayers and mandate for the state finance management.

\subsubsection{Legitimacy Theory}

According to O'Donovan (2002), legitimacy theory is based on the idea that an organization in order to continue its operation so that the organization must act within the limits of acceptable behaviors by the social environments. The organization will create harmony all of its activities with the social norms of society where the organization is located. As long as the work program and the activities of the organization are aligned, then the existences and the activities of the organization can be legitimated.

Dowling and Pfeffer (1975) state that this theory is based on the social contract which takes place between the organization with the society in which the organization use of economic resources. If there is a difference between the value of the organization and the social values of society, the legitimacy of the organization is threatened. The difference value is often called the legitimacy gap that may affect the organization's ability to continue its activities. Clark (1956) provides an example of the value changes that occur as a consequence of organizational adaptation to the environment. In the initial transformation process in adjusting with the problems, changes in the organization could establish the value of the larger society. The second source of change in norms and social values could come from competition between the organizations that focus on social values with other organizations. The survival of the organization is enhanced by legitimacy which could be seen as a resource that is given to organizations that 
sometimes organizations are competing to win. The legitimacy of the organization is determined by the operation method, output and activity objectives of the organization. Dowling and Pfeffer (1975) state that legitimacy is a constraint, but is a dynamic obstacle that adapts as organizations, and as a social value that determines legitimacy change.

\subsection{The Disclosure Compliance of Financial Information on Website}

The Disclosure of financial information on the website is also called the Internet Financial Reporting (IFR). IFR according to Asbaugh, et al. (1999) is the distribution of financial information and performance information using Internet technologies such as the world wide web. The website can be used by the local governments to provide the financial information that is considered necessary for the stakeholders, to update the data at any time, to introduce regional superiority. It is known that every local government's website provides a feature "online chat" to allow the public could communicate directly with local governments. By using this feature can reduce the cost of relations with the stakeholders. Thus, the disclosure of financial information by using internet media, not only to accelerate the delivery of information and feedback from the community but also to increase the quantity of disclosure of financial information. This condition can eventually increase transparency and reduce the problem of the information asymmetry (Mardiati, 2011)

\subsection{Hypothesis Development}

2.3.1 Financial Performances (The absorption of local expenditure ratio, The effectiveness, The local independence ratio)

The financial performance of local governments is related to the local government achievement in gaining the revenues and using the funds for the benefit of the wider community whether those are on target or not (Nugroho, 2012). Financial performance is one measure of their success in managing the government. The good performance means that the local government manages the programs and the activities successfully. The local governments having good financial performances will attempt to express and spread the good news to the public as quickly and widely as possible (Hiola, et al., 2016).

Laswad et al. (2005) find that the performance of local government is associated with the internet financial reporting. While Suhardjanto and Lesmana (2010) and Hiola et al. (2015) have similar findings. Suhardjanto and Lesmana (2010) find that the independence level of local government has a positive influence on mandatory disclosure of local government in the financial statements. Furthermore, Hiola, et al. (2015) suggest that the financial performance indicators represented by the absorption of local expenditures ratio, the effectiveness ratio, and the independence ratio are associated with the disclosure of financial information on the website.

The previous results are expected similar results of this study, so the hypothesis is as follows:

- $\mathrm{H}_{1}$ : The absorption of local expenditure ratio is associated with the disclosure compliance of finance information on the website.

- $\mathrm{H}_{2}$ : The effectiveness is associated with associated with the disclosure compliance of finance information on the website.

- $\mathrm{H}_{3}$ : The local independence ratio is associated with associated with the disclosure compliance of finance information on the website. 


\subsubsection{Audit Opinion As A Moderating}

According to Hiola et al. (2015) financial statement examination is one of the ways to control local governments. The better audit opinion of local government financial statements, the better quality financial statement disclosure of local government. Andriani (2012) examines the association between audit opinion and disclosure qualities. Andriani (2012) suggests that audit opinion is associated with the disclosure qualities of local government finance information. While Hapsoro (2010) examines the association between audit qualities and CSR disclosures and He suggests that audit quality is positively associated with CSR disclosure. The excellent audit opinion is gained from good local government performances. Hiola et al. (2015) state that qualified audit opinion could strengthen the influence of financial performance on the disclosure compliance of local government financial information on the website.

Those studies could moderate the influence of financial performance represented the absorption of local expenditures ratio, the effectiveness ratio and the independence ratio on the disclosure compliance of financial information on website (IFR)

- $\mathrm{H}_{4}$ : Audit opinion moderates relationship between the absorption of local expenditures ratio on the disclosure compliance of financial information on website (IFR)

- $\mathrm{H}_{5}$ : Audit opinion moderates relationship between the effectiveness ratio on the disclosure compliance of financial information on website (IFR)

- H6: Audit opinion moderates relationship between the independence ratio on the disclosure compliance of financial information on website (IFR)

\section{RESEARCH METHOD}

\subsection{Population and Sample}

This research is a descriptive quantitative research with the population using local governments in Java Island. The total number of all local governments is 125 , which have financial statements reporting amounted to 119 . This study uses 3 year period data from 2012 up to2014, so that the data use panel data. Sampling technique uses purposive sampling with criteria are local governments have authorized website which can be accessed and have financial performances data completely (local government expenditures, local revenues, the central government /provincial transfer, and local loans) during period 2012 up to 2014. Based on these criteria obtained a final sample of 24 .

Table 1 Research Sampling

\begin{tabular}{|l|c|}
\hline $\begin{array}{l}\text { Local governments (LGs) in Java Island which have Financial } \\
\text { Statements }\end{array}$ & 119 \\
\hline LG Websites can not be accessed & 7 \\
\hline LG Websites can be accessed and have Financial Statements & 112 \\
\hline $\begin{array}{l}\text { Incomplete Financial Performance of LGs sourced by Directorate } \\
\text { General Fiscal Balance, Ministry of Finance }\end{array}$ & 31 \\
\hline Selected LGs in the study & 81 \\
\hline Year & 3 \\
\hline Total number of samples during 3 years (from 2012 up to 2014) & 243 \\
\hline
\end{tabular}


The Moderating Effect of Audit Opinion on The Local Government Financial Performances and The Disclosure Compliance of Financial Information

\subsection{Types and Sources of Data}

The data used in this research is secondary data collected from the source of documents government publications, analysis of various printed and electronic media, Internet. IFR obtained from Local Budget Management Transparency Contents form all local government websites. All authorized websites are sourced from Ministry of Home Affairs website. The local government financial performances are sourced from Local Budget and Realized Local Budget either those come from Directorate General of Fiscal Balance sources or Local Government websites. Local Governments Audit Opinion are the source from The Summary of Second Mid Year of 2015 on Audit Supreme Board website.

\subsection{Research Model} follows :

The Multiple regression models which is used to test the hypotheses as

$$
\begin{aligned}
& I F R_{\text {it }}=\beta_{0}+\beta_{1} A_{L E} \text { it }+\beta_{2} \mathrm{EFF}_{\text {it }}+\beta_{3} \mathrm{LI}_{\text {it }}+\beta_{4} \mathrm{OP}_{\text {it }}+\beta_{5} \mathrm{ALE}_{\mathrm{it}} * \mathrm{OP}_{\text {it }}+\beta_{6} \\
& \mathrm{EFF}_{\text {it }} * \mathrm{OP}_{\text {it }}+\beta_{7} \mathrm{LI}_{\mathrm{it}} * \mathrm{OP} \text { it }+\varepsilon_{\text {it }}
\end{aligned}
$$

Abbreviations :

IFR = Internet Financial Reporting Scores

ALE $\quad=$ Absorption of Local Expenditures Ratio

EFF $=$ Effectiveness Ratio

LI = Local Independence Ratio

$\mathrm{OP}=$ Audit Opinion

$\varepsilon \quad=$ error

\subsection{Variable Proxy}

The proxy of the Variables in the study are as follows:

\begin{tabular}{|c|c|c|c|}
\hline No. & Variable & Description & Proxy \\
\hline \multirow[t]{2}{*}{1} & \multirow[t]{2}{*}{ IFR } & \multirow{2}{*}{$\begin{array}{l}\text { The disclosure compliance } \\
\text { of financial information on } \\
\text { website }\end{array}$} & website disclosures scores \\
\hline & & & total disclosures scores \\
\hline \multirow[t]{2}{*}{2} & \multirow[t]{2}{*}{ ALE } & \multirow{2}{*}{$\begin{array}{l}\text { Absorption of Local } \\
\text { Expenditures Ratio }\end{array}$} & Local ExpendituresRealization \\
\hline & & & Local Expenditures Budget \\
\hline \multirow[t]{2}{*}{3} & \multirow[t]{2}{*}{$\mathrm{EFF}$} & \multirow[t]{2}{*}{ Effectiveness Ratio } & Local Revenues Realization \\
\hline & & & Local Revenues Budget \\
\hline \multirow[t]{2}{*}{4} & \multirow[t]{2}{*}{ LI } & \multirow[t]{2}{*}{ Local Independence Ratio } & Local Revenues Realization \\
\hline & & & $\overline{\text { Central Government Transfer Funds + Local L }}$ \\
\hline 5 & $\mathrm{OP}$ & Audit Opinion & $\begin{array}{c}\text { Score } 4 \text { for unqualified opinion, Score } 3 \text { for qualified } \\
\text { opinion, Score } 2 \text { for adverse opinion, score } 1 \text { for } \\
\text { disclaimer }\end{array}$ \\
\hline
\end{tabular}

Table 2 Variables Proxy

\section{RESULTS AND DISCUSSION}

\subsection{Descriptive Statistics}

Descriptive statistics provide a figure of concentration and dispersion of data from the variables consisting of the average value (average), minimum, maximum, mean, and standard deviation. Descriptive statistics can be seen in as follows: 
Table 3 Descriptive statistics

\begin{tabular}{cccccc}
\hline Variable & Mean & Median & Minimum & Maximum & Std. Dev. \\
\hline IFR & 0,2444 & 0,1200 & 0,0000 & 1,0000 & 0,2876 \\
ALE & 0,9892 & 0,9805 & 0,5939 & 2,4579 & 0,1438 \\
EFF & 1,3134 & 1,2844 & 0,7202 & 2,4105 & 0,2117 \\
LI & 0,3196 & 0,1524 & 0,0391 & 2,5696 & 0,4570 \\
OP & 3,3498 & 3,0000 & 1,0000 & 4,0000 & 0,6005 \\
\hline
\end{tabular}

1. The average of the compliance disclosure of financial information on the local government websites (IFR) in Java Island for the period 2012 until 2014 is 0.2444 . This means that the average local government in Java Island providing the disclosure of financial information on the website is only $24.44 \%$ of the provisions of Instruction of Minister of Home Affairs. The standard deviations greater than the mean in the amount of $28.76 \%$ indicates that there is a disparity in the distribution of data from the lowest and highest IFR.

2. The average of the absorption of local expenditures is 0.9892 with a standard deviation of 0.1438 . The average ratio is very close to 1 indicates that the state budget is absorbed well.

3. The average of the effectiveness ratio is 1.3134 with a standard deviation of 0.2117 . The effectiveness ratio, the more effective local revenues collection.

4. The average of the local independence ratio is 0.3196 with a standard deviation of 0.4570 . The higher the local independence ratio, the lower the independence of a local government on central government provincial transfers funds and loans.

5. The Average of audit opinion is 3.3498 with a standard deviation of 0.6005 . This shows that the average local governments financial statements in the area of Java have gained at least qualified audit opinion.

\subsection{Hypothesis Tests}

After examining model selection in panel data and classical assumption, the regression model in this study uses fixed effect model with the confidence level, of $95 \%$,

\subsubsection{The coefficient of determination test (Adjusted R Square)}

The test is aimed to measure how far the ability of the model to explain variations in the dependent variable. The value of adjusted $\mathrm{R} 2$ in the regression model is equal to 0.6125 . The adjusted $\mathrm{R} 2$ value indicates that the independent variables can only explain 61.25 percent of the variation in the variable compliance of financial information disclosure on the website (IFR) while the rest influenced by other variables outside variables in the model in this study.

\subsubsection{Simultaneous Significance Test (Test F)}

The statistical $\mathrm{F}$ test basically indicates whether all the independent variables included in the model have a simultaneous effect on the dependent variable. If the statistical probability value $<0.05$ (significant), means that all independent variables simultaneously affect the dependent variable. Conversely, if the value of a statistical probability of $>0.05$ (not significant), means that all independent variables simultaneously have no effect on the dependent variable. $F$ test result shows the value of F-statistic 5.396317 while the value of the F statistic probability is 0.0000 so that all independent variables simultaneously affect the dependent variable. 
The Moderating Effect of Audit Opinion on The Local Government Financial Performances and The Disclosure Compliance of Financial Information

\subsubsection{Partial Significance Tests (t-test)}

The statistical test $t$ basically shows how much influence one explanatory variable on the dependent variable individually. If the statistical probability value $<0.05$, the independent variables affect the dependent variable, then the hypothesis is accepted. If the statistical probability value $>0.05$, the independent variable has no effect on the dependent variable, then the hypothesis is rejected.

Table 4 The Output of Regression Test

\begin{tabular}{cccl}
\hline Variable & Coefficient & t-Statistic & Prob. \\
\hline ALE & $-0,016430$ & $-0,130615$ & 0,8962 \\
EFF & 0,329624 & 3,980540 & 0,0001 \\
LI & 0,456180 & 3,035318 & 0,0028 \\
OP & 0,060948 & 2,158118 & 0,0325 \\
ALE*OP & $-0,014962$ & $-0,635485$ & 0,5260 \\
EFF*OP & 0,007090 & 0,380896 & 0,7038 \\
LI*OP & $-0,029623$ & $-1,986350$ & 0,0488 \\
\hline
\end{tabular}

- Variable ALE has a probability value of 0.8962 . $\beta$ coefficient value is negative 0.016430 . Due to the significant value of 0.8962 exceeding 0.05 means that $\mathrm{H} 1$ is rejected or, in other words the absorption of local expenditures ratio is not associated with the disclosure compliance of financial information on the website (IFR).

- Variable EFF has a probability value of 0.0001 . $\beta$ coefficient value is positive 0.329624 . Due to the significant value of 0.0001 is less than 0.05 means that $\mathrm{H} 2$ is not rejected or in other words the effectiveness ratio is positively associated with the disclosure compliance of financial information on the website (IFR).

- Variable LI has a probability value of 0.0028 . the $\beta$ coefficient value is positive 0.456180 . Due to the significant value of 0.0028 is less than 0.05 means that $\mathrm{H} 3$ is not rejected or in other words the local independence ratio is associated with the disclosure compliance of financial information on the website (IFR).

- Variable ALE * OP has a probability value of 0.5260 . The coefficient value of PBD * OPINION is -0.014962 . Due to the significant value of 0.5260 greater than 0.05 means $\mathrm{H} 4$ is rejected or, in other words the audit opinion can not moderate the effect absorption of local expenditure ratio on compliance disclosure of financial information on the website (IFR).

- Variable EFF * OPI has a probability value of 0.7038 . The coefficient value of EFF * OPI is 0.007090 . Due to the significant value of 0.7038 greater than 0.05 means that $\mathrm{H} 5$ is rejected or, in other words the audit opinion can not moderate the effect of the effectiveness ration to the disclosure compliance of financial information on the website (IFR).

- $\quad$ Variable LI * OP has a probability value of 0.0488 . The coefficient value LI * OP is -0.029623 . Because of the 0.0488 significance value less than 0.05 means that $\mathrm{H6}$ is not rejected or in other words the audit opinion moderate the effect of the local independence ratio on the disclosure compliance of financial information on the website (IFR).

\subsection{DISCUSSIONS}

\subsubsection{The Effect of Absorption of Local Expenditures Ratio on IFR}

The result shows that the absorption of local expenditures is not associated 
with the disclosure compliance of financial information on the website (IFR) so that the first hypothesis (H1) is rejected. Under the provisions of Article 298 of Law No. 23 of 2014 concerning Local Government, that the local expenditures are prioritized to provide services to the community. Absorption of high local expenditures does not necessarily reflect the high level of services. Furthermore, it does not encourage local government to disclose financial information on the website. This result is relevant with Puspita and Martani (2012), but it is not relevant with Hiola, et al. (2015). The difference of result may be due to differences in the period of the study using three periods and the absorption of local expenditure ratio becomes more fluctuating.

\subsubsection{The Effect of Effectiveness Ratio On IFR}

The results show that the effectiveness ratio has a significant effect on the disclosure compliance of financial information on the website. The higher local revenues realizations in one local government, the level of the disclosure compliance of financial information on the website will be higher. The result is consistent with Suhardjanto and Lesmana (2010). Local revenues can be sourced from local taxes and levies which are a form of participation of the local societies. Local governments with higher revenue realization mean that the citizens are more obedient to pay taxes and levies. Suhardjanto and Lesmana (2010) argue that the citizens are obedient to pay taxes to tend to be more supervise the local government performances so that the local government will conduct the widest disclosures included disclose financial information on the website in order to achieve transparency of financial managements. The result of this study is also consistent with Laswad, et al. (2005), Setyaningrum and Syafitri (2012), and Hiola et al. (2016), which the financial performance has a significant effect on the disclosure compliance of financial information on the website. Local governments are aware that information regarding the effectiveness of revenue generation is an important performance indicator because local revenues are closely related to direct participation of the citizens, especially in paying taxes and levies. Local governments are encouraged to disclose financial information to show the public how effective local revenues generated on its territory as a form of accountability to public participation.

\subsubsection{The Effect of Local Independence Ratio On IFR}

The result of the study shows that the local independence ratio is positively associated with the disclosure compliance of financial information on the website. The result of this study supports Suhardjanto and Lesmana (2010) which shows that the level of local independence has a positive influence on local government mandatory disclosure in the financial statements. The local independence ratio is well aligned with the effectiveness ratio for local revenues as the same elements. If the effectiveness ratio of encouraging local government to account for its performance to the citizens in the regions, then the same thing applies to the local independence ratio. Besides being able to demonstrate the financial capacity of the region, the local independence ratio of local government to disclose its financial information as a form of accountability both to internal and to external parties. The audit opinion can not moderate effect absorption ratio shopping areas of compliance disclosure of financial information on the website.

\subsubsection{Audit Opinion As A Moderating The Association Between Absorption Of Local Expenditures Ratio and IFR}

The result shows the involvement of audit opinion can not moderate the 
association between the absorption of local expenditures ratio to the disclosure compliance of financial information on the website. This evidence reflects that local governments with good absorption of local expenditures and getting unqualified opinions have a low level of the disclosure compliance of financial information on the website such as Semarang City, Banjar Regency, and Kulon Progo Regency. The result is not relevant with Hiola, et al. (2016) which shows the audit opinion can moderate the effect of financial performance (one indicator is the absorption of local expenditures) on the disclosure compliance of financial information on the website. The difference result is expected there is the difference in the period of research because the local expenditures may fluctuate from year to year.

\subsubsection{Audit Opinion As A Moderating The Association Between Effectiveness Ratio and IFR}

The results show that the involvement of audit opinion can not moderate the association between the effectiveness ratio and the disclosure compliance of financial information on the website. The result is different from Hiola, et al. (2016) which suggests the audit opinion can moderate the effect of financial performance on the disclosure compliance of financial information on the website. This difference may be due to the interaction of moderating variables in previous studies carried out jointly for all financial performance indicators, while in this study the examination of the interaction of moderating variables conducted separately for each of the indicators of financial performance so that it obtains the different results for each indicator.

\subsubsection{Audit Opinion As A Moderating The Association Between Local Independence Ratio and IFR.}

The result of the study shows that audit opinion can moderate the association between the local independence ratio to the disclosure compliance of financial information on the website. The coefficient this association is negative. It means that the more qualified audit opinion will weaken the association between the local independence ratio to the disclosure compliance of financial information on the website. The result is relevant with Hiola et al. (2016). The audit opinion seems to be a consideration in the local government disclose its financial information on a website because the audit opinion of the local government is seen as a reflection of its performance. Audit opinion significant and negative influence as a moderating means that local governments which gain unfavorable audit opinions are encouraged to disclose financial information on the website. It is expected that this condition conducted by the local government as an effort to balance the public assumptions on the audit opinion has been obtained. Meanwhile, local governments obtain audit opinions are fairly good not to encourage to disclose their financial information, especially related to financial independence on the website.

\section{CONCLUSION}

The condition of financial disclosures on the website of each local governments in the area of Java for the year 2012 up to 2014. There are some local governments that already disclose all financial information as required by the Minister of Home Affairs Instruction No. 188-52 / 1797 / SJ of 2012 on Improving Transparency of Local Budget Management, but there are still many local governments do not fully required disclosure. The result suggests that the level of disclosure compliance with financial information on the website of the local 
government in the area of Java during 2012 s.d. 2014 is still low. In addition, there is a lack of uniformity in financial information presentation of local government on the website.

Of the independent variables used in the study, it is known that the only variable the absorption of local expenditures is not associated with the disclosure compliance of financial information on the website. It is expected that the absorption of local expenditures rate has not always reflected the level of service provided to the public so it does not encourage local government to fulfill the compliance with the disclosure of financial information on the website. Meanwhile, two other variables, the effectiveness ratio and the local independence ratio suggest the positive impact on the disclosure compliance of financial information on the website. The results reflect that if the effectiveness ratio and the local independence ratio increase, there will be also improving the disclosure compliance of financial information on the website.

The audit opinion directly (without involving interaction with the independent variable) shows a significant influence on the disclosure compliance of financial information on the website. However, if it interacts with independent variables, it will give different results. The interaction between audit opinion and the absorption of local expenditures ratio as well as the effectiveness ratio result that audit opinion can not moderate the association between the absorption of local expenditures ratio and the effectiveness ratio on the disclosure compliance of financial information on the website.

Meanwhile, the interaction between audit opinion and local independence ratio suggests the negative effect on the disclosure of financial information on the website. The negative effect indicates that the audit opinion can weaken the association between local independence ratio on the disclosure compliance of financial information on the website.

This research has several limitations :

1. The object of the study is limited in the local government area of Java and only three-year study period.

2. The data obtained and processed from any kind of sources are still much less complete due to reduced number of observations. By adding objects and coverage period as well as looking for other data sources is expected to further studies will have a greater number of observations.

3. The study was conducted only by involving the three indicators of financial performance.

Based on the limitation mentioned above, it is suggested for future research as follows :

1. Future research should be able to expand the scope of the object and the period.

2. Future research should add objects and coverage period as well as looking for other data sources expected to further studies will have a greater number of observations.

3. Future research should expand other financial performance measures and nonfinancial performance variables.

\section{References}

Andriani, E. (2012). Pengaruh Opini Audit dan Temuan Audit Terhadap Tingkat 
The Moderating Effect of Audit Opinion on The Local Government Financial Performances and The Disclosure Compliance of Financial Information

Pengungkapan pada Laporan Keuangan Pemerintah Daerah. Program Ekstensi Akuntansi Fakultas Ekonomi Universitas Indonesia.

Anthony, R. N. (1978). Financial Accounting in Nonbusiness Organizations: An Exploratory Study of Conceptual Issues: Research Report. Stamford, Conn: Financial Accounting Standards Board.

Asbaugh, H., Johnstone, K. M., \& Warfield, T.D. (1999). Corporate Reporting on the Internet. Accounting Horizon, 13(3).

Badan Pemeriksa Keuangan. (2015). Ikhtisar Hasil Pemeriksaan Semester II Tahun $2015 . \quad$ http://www.bpk.go.id/assets/files/ihps/2015/II/ihps_ii_2015 _1460449853.pdf. (diakses pada 28 Oktober 2016).

Badan Pusat Statistik. (2016). Statstik Indonesia 2016. https://www.bps.go.id/website /pdf_publikasi/Statistik-Indonesia-2016-.pdf. (diakses pada 28 Oktober 2016).

Badjuri, A., \& Trihapsari, W. (2004). Audit Kinerja pada Organisasi Sektor Publik Pemerintah. Fokus Ekonomi. Agustus 2004.

Bryson, J. M. (1995). Strategic Planning for Public and Nonprofit Organizations (rev. ed), San Francisco. CA: Jossey- Bass.

Clark, B. R. (1956). Organizational Adaptation and Precarious Value: a Case Study. American Sociological Review, 21, 327-336.

Dowling, J., \& Pfeffer, J. (1975). Organizational Legitimacy: Social Values and Organizational Behavior. The Pacific Sociological Review, 18(1), 122136.

Daftar Nama Gubernur dan Wakil Gubernur, Bupati dan Wakil Bupati, serta Walikota dan Wakil Walikota Seluruh Indonesia. http://otda.kemendagri.go.id/. (diakses pada 29 Oktober 2016).

Drebin, A. R., Chan, J. L., \& Ferguson, L. C. (1981). Decisions and Information Needs of Governmental Accounting Information Users. Chicago: National Council on Governmental Accounting, 4-18.

Freeman, R. E. (1984). Strategic Management: A Stakeholder Approach. Boston, MA: Pitman.

Hapsoro, D. (2010). Pengaruh Corporate Governance dan Kualitas Audit Terhadap Pengungkapan Corporate Social Responsibility. Jurnal Akuntansi dan Manajemen, 23(3), Desember 2012, 199-215.

Hiola, Y., \& Rusidi, A. D. M. (2016). Political Environment in The Effect of The Regional Government Financial Performance on Disclosure of Financial Information on Website. Journal of Economics, Business, and Accountancy 
Ventura, 19(1), April - July, 27 - 36.

Hiola, Y., \& Rusidi, A. D. M. (2015). Pengaruh kinerja keuangan terhadap kepatuhan pengungkapan informasi keuangan di website dengan opini audit dan lingkungan politik sebagai pemoderasi (studi pada pemerintah provinsi, kota, dan kabupaten di Sulawesi). Simposium Nasional Akuntansi 18 Medan. 16-19 September 2015.

Kementerian Dalam Negeri. Peraturan Menteri Dalam Negeri Nomor 13 Tahun 2006 tentang Pedoman Pengelolaan Keuangan Daerah.

Keputusan Menteri Dalam Negeri Nomor 690.900-327 Tahun 1996 tentang Pedoman Penilaian dan Kinerja Keuangan.

Instruksi Menteri Dalam Negeri Nomor 188-52/1797/SJ Tahun 2012 tentang Peningkatan Transparansi Pengelolaan Anggaran Daerah.

Laswad, F., Fisher, R., \& Oylere, P. (2005). Determinants of voluntary Internet financial reporting by local government authorities. Journal of Accounting and Public Policy, 24, 101-121.

Mardiati, E. (2011). Determinan penyebaran informasi keuangan melalui website pada perusahaan publik di Indonesia. Disertasi. Program Doktor Ilmu Akuntansi Universitas Brawijaya.

Martani, D., \& Lestiani, A.. (2012). Disclosure in local government financial statements: the case of Indonesia. Global review of Accounting and Finance, 3(1), March 2012, 67-84.

Nugroho, F. (2012). Pengaruh Belanja Modal Terhadap Pertumbuhan Kinerja Keuangan Daerah Dengan Pendapatan Asli Daerah Sebagai Variabel Intervening (Studi Kasus di Propinsi Jawa Tengah). [Skripsi]. Semarang: Universitas Diponegoro.

O'Donovan, G. (2002). Environmental Disclosures in the Annual Report Extending the Applicability and Predictive Power of Legitimacy Theory. Accounting, Auditing and Accountability Journal, 15(3), 344-371.

Puspita, R., \& Martani, D. (2012). Analisis pengaruh kinerja dan karakteristik Pemerintah Daerah terhadap tingkat pengungkapan dan kualitas informasi dalam website Pemerintah Daerah. Simposium Nasional Akuntansi 15 Banjarmasin. 20-23 September 2012.

Republik Indonesia. Undang-Undang Nomor 17 Tahun 2003 tentang Keuangan Negara 
The Moderating Effect of Audit Opinion on The Local Government Financial Performances and The Disclosure Compliance of Financial Information

Undang-Undang Nomor 15 Tahun 2004 tentang Pemeriksaan Pengelolaan dan Tanggung Jawab Keuangan Negara.

\section{Daerah.}

Undang-Undang Nomor 32 Tahun 2004 tentang Pemerintahan

Undang-Undang Nomor 14 Tahun 2008 tentang Keterbukaan Informasi Publik.

Peraturan Pemerintah No. 71 Tahun 2010 tentang Standar Akuntansi Pemerintahan.

Instruksi Presiden Nomor 3 Tahun 2003 tentang Kebijakan dan Strategi Nasional Pengembangan E-Government.

Suhardjanto, D., \& Lesmana, S. I. (2010). Pengaruh Karakteristik Pemerintah Daerah Terhadap Tingkat Pengungkapan Wajib di Indonesia. Prestasi 6(2), $25-40$.

Xiao, J. Z., Jones, M. J., \& Lymer, A. (2005). A Conceptual Framework for Investigating the Impact of the Internet on Corporate Financial Reporting. The International Journal of Digital Accounting Research, 5(10), 131-169.

Yu, H. (2010). On the determinants of internet-based disclosure of government financial information. Management and Service Science. International conference on 24-26 Agustus 2010. 